DOI 10.33979/ 978-5-9708-0824-5-2020-1-0-123-132

\title{
INTERACTION BETWEEN AL-FARABI KAZNU WITH EMPLOYERS AND STUDYING EXPERIENCE OF EMPLOYMENT GRADUATES AND VOCATIONAL GUIDELINES OF EU UNIVERSITIES
}

\section{ВЗАИМОДЕЙСТВИЕ КАЗНУ ИМ. АЛЬ-ФАРАБИ С РАБОТОДАТЕЛЯМИ И ИЗУЧЕНИЕ ОПЫТА ТРУДОУСТРОЙСТВА ВЫПУСКНИКОВ И ПРОФОРИЕНТАЦИОННОЙ РАБОТЫ УНИВЕРСИТЕТОВ ЕВРОСОЮЗА}

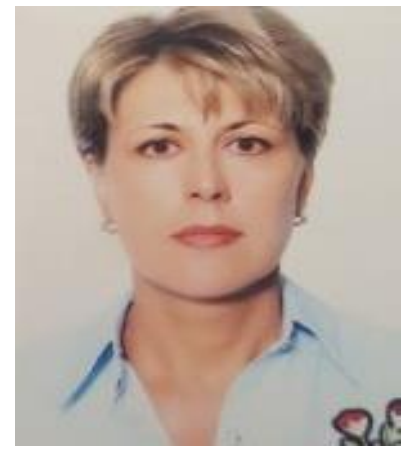

e-mail:

Abstract

Аннотация

\section{Oksana Yu. KOGUT}

senior lecturer of the Department «Finance and accounting» of the Higher school of Economics and business of the al-Farabi Kazakh national University, doctoral student (Almaty, Kazakhstan)

\section{КОГУТ Оксана Юрьевна}

старший преподаватель кафедры «Финансы и учет»

Высшей школы экономики и бизнеса Казахского

национального университета имени аль-Фараби? докторант (г. Алматы, Казахстан)

kogut.1108@gmail.com

The article discusses the interaction of Al-Farabi KazNU with employers, the activities of the Career and Professional Development Center, the concept of continuous practical training of students, the work of the Job / Internship Fair, the activities of the KazNU Employers Council, initiated by the Career Sector, and the study of the experience of cooperation between business universities of EU universities within the framework of Enhancement of Higher Education and Corporate Sectors Integration in Accordance with New Social Environment project / Improving the integration of higher education and corporate sectors in accordance with social environment -ENINEDU

В статье рассматривается взаимодействие КазНУ имени аль-Фараби с работодателями, деятельность Центра Карьеры и профессионального развития, концепция непрерывной практической подготовки обучающихся, работа Ярмарки вакансий/стажировок, деятельность Совета работодателей КазНУ, инициированного Сектором карьеры, изучение опыта сотрудничества бизнес-вузов университетов ЕС в рамках проекта «Enhancement of Higher Education and Corporate Sectors Integration in Accordance with New Social Environment» («Улучшение интеграции высшего образования и 
Направление 2. Сотрудничество бизнеса и вузов: лучиие европейские практики. Российский и Казахский onblm

корпоративных секторов в соответствии с новой социальной средойENINEDU»)

Keywords graduates, employers, Career Center, Council of Employers, practice base, academic mobility

Ключевые слова выпускники, работодатели, Центр карьеры, Совет работодателей, база практики, академической мобильности

\section{Introduction}

Al-Farabi Kazakh National University has a Career and Professional Development Center. The goal of the center is to form the personnel potential of competitive specialists who meet modern intellectual requirements and the development strategy of the Republic of Kazakhstan that meet international standards. The tasks are the formation of a modern subsystem of demand for specialists, attracting employers to conduct master classes, trainings and presentations for students and graduates of the university, developing a system for promoting employment and adapting KazNU graduates to the labor market, as well as developing educational programs with employers.

The activities of the Center are focused on the implementation of the concept of continuous training, optimization of the development and strengthening of relations between KazNU and enterprises and organizations. The center is a link between enterprises, specialized departments, graduates and the university administration.

A competitive specialist - a graduate of KazNU - must possess not only theoretical knowledge in his field, but also additional competencies for a successful career.

Al-Farabi Kazakh National University has established close contacts with the largest companies that are guided by the world market and present corresponding requirements for the level of training.

The activities of this center contribute to the expansion of student practice bases and their further employment. The center holds training seminars, "open days" for employers, leadership lectures of famous people and graduates of KazNU held.

Also, the center, together with partners-employers, annually makes presentations of practice bases and student internships, workshops and webinars. Over the past 3 years, the center has held various thematic marketing seminars and trainings on the current state and main areas of development of the Kazakhstan labor market.

Based on the implementation of the State Program for the Development of Education in the Republic of Kazakhstan, Al-Farabi KazNU Center for Career and Business has developed a new concept of continuous practical training of students.

In order to strengthen the university's interaction with employers, a Council of Employers is functioning at KazNU, which includes a number of large companies and organizations. Through the activities of the Council of Employers, employing companies are involved in the development and examination of work curricula and curricula of disciplines in all specialties. 
For the participation of companies and employers in the employment of graduates, a Job / Internship Fair is held every year. More than 100 leading Kazakhstani and international companies and organizations actively participate in the fair annually, attracting young specialists for temporary and permanent work.

A fair of vacancies / internships is annually attended by 5-6 thousand graduate and senior students of KazNU. Of these, more than half of the students receive an offer to get an interview at the company. As part of the job fair, master classes and seminars are held where graduates take information on employment and social and legal protection of university graduates within the framework of anti-crisis measures developed by the state. Since 2014, the job fair has been held in a new international format, with the involvement of foreign investors and other employers.

The library of al-Farabi KazNU hosts the annual Job Fairs «Path to Success!» KazNU. The main goal of the fair is to facilitate the employment of graduates of KazNU, to help them build a successful career.

Within the framework of the fair, employers participate in various master classes, trainings and seminars for applicants. According to the organizers, this is an additional tool and skill for students and graduates during interviews.

Analysis of the employment market for graduates is also conducted by the Ministry of Education and Science of the Republic of Kazakhstan with the help of pension contributions. This method is used in the USA.

It should be noted that at each faculty of KazNU there is a Council of employers, there is a plan for employment through the targeted distribution of graduates. The Career and Business Center of KazNU is also actively working in this direction.

KazNU graduates are characterized by mobility, seriousness of motivation for the profession, a tendency to self-development, hard work, communication skills and creativity.

Employers of KazNU, such as: NAC KazAtomProm JSC, KazTransGas, Kazakhstan Engineering, Almaty Chamber of Entrepreneurs Atameken, Foodmaster, Danon-Berkut, APPLE CityDistributors, Philip Morris Kazakhstan, Mars Kazakhstan, National Bank of Kazakhstan, Kazkommertsbank, People's Bank Kazakhstan, Sberbank, and other companies annually employ more than 2,000 graduates and employ more than 3,000 students of Al-Farabi Kazakh National University for internships.

Every year, a meeting of the KazNU Employers Council, initiated by the Career Sector, is held at Al-Farabi Kazakh National University.

Participants of the meeting of the Council of Employers of KazNU present practical examples of interaction between the university and employers, which give KazNU students the opportunity to acquire knowledge and skills that are in demand in the real sector of the economy. In addition, the meeting discusses new initiatives by employers and the university in this area, as well as specific steps that can and should be taken by the university so that graduates receive an education that meets the requirements of employers. 
Направление 2. Сотрудничество бизнеса и вузов: лучиие европейские практики. Российский и Казахский onblm

The mission of the Council of Employers of KazNU is to promote the development of the university as a center for the training of highly qualified competitive specialists.

The KazNU Employers Council includes the largest companies representing various fields of activity and the country's economy: Microsoft Kazakhstan, KPMG, HSBC, Samruk-Kazyna National Welfare Fund, People's Bank of Kazakhstan, Kazatomprom national company, National Space Agency, national scientific and technological holding Parasat, GSM Kazakhstan mobile operator, Kazphosphate, national company KazMunayGas, Eurasian Bank JSC, El Arna shopping center and others.

The main issues for discussion at the meeting of the Council of Employers:

- Creation and development of a system of grants for students and teachers; participation of the Ministry of Education and Science of the Republic of Kazakhstan in the development of academic mobility;

- Improvement of organizational mechanisms and intra-university normative and methodological support of academic mobility;

- Ensuring high-quality training of students, teachers and university staff in foreign languages, forming an adequate level of language proficiency for participation in international cooperation programs;

- Development of an intra-university system for assessing mobility;

- The creation of social conditions, the development of academic mentoring;

- Development of a system of informing about academic mobility programs;

- Attracting employees of research organizations and practitioners from the market to develop practical skills among students; modules;

- The development of academic mobility based on short-term courses,

- Improving English;

- Teaching individual modules, subjects in English, individual specialties;

- The introduction of mobile Internet for research;

- Employment issues for graduates and interactions with employers.

The Al-Farabi Kazakh National University has an information portal called Youth and Career. The purpose of the information portal is to automate university activities aimed at providing graduates with jobs.

The portal aims to implement a new mechanism for the interaction of educational institutions and the labor market, taking into account the market mechanism of supply and demand:

- the formation and updating of databases of vacancies and resumes of students and graduates;

- Formation and updating of databases of employers, vacancies, bases of practices and internships;

- the implementation of active forms and methods of interaction between employers and students;

- interaction with employers in regional labor markets and feedback from university graduates;

- interaction of employers with the university; 
- formation of ratings, statistics and reports on the automation object.

Since October 2016, Al-Farabi Kazakh National University has been the coordinator of the project "Enhancement of Higher Education and Corporate Sectors Integration in Accordance with New Social Environment" - ENINEDU. The following people participate in the project: Al-Farabi Kazakh National University (Kazakhstan), Santiago Compostela University (Spain), Nice-Sophia Antipolis University (France), Sopron University (Hungary), Peoples' Friendship University of Russia (Russia), Samara State University of Economics (Russia), I.S. Turgenev Orel State University (Russia), L.N. Gumilyov Eurasian National University (Kazakhstan).

The purpose of the project is to study the practical value of modern methods, their place in the curriculum and curricula and the measurement of learning outcomes, the preparation of a comprehensive standard in the system of cooperation of a business university, suitable for each partner country, analytical studies on the reference national legislation in the EU countries in relation to university cooperation with business.

\section{Research methods}

Forecasting the need for specialties is necessary to meet the requirements of consumers (students, parents of students, organizations, society). This work is carried out by the selection committee on the basis of evidence: the requirements of customers to the competencies of graduates; graduate employment results, questionnaires / reviews of graduates and organizations; wishes and preferences of applicants (survey results). Data on the results of employment should provide graduating departments and faculties.

The wishes and preferences of applicants are usually determined by a survey. Such a survey can be carried out: when attending schools; through a telephone survey; via the internet. Indirect information for determining the desires and preferences of applicants can be obtained: from official statistics; from specialized publications; from population survey agencies; according to statistics for the last receiving company (the number of applications submitted).

Customer requirements are determined by written requests to the organization. In this case, it is desirable to obtain from them the qualifications of the required specialists. When forecasting, it is also necessary to take into account: the demographic curve (increase or decrease in school graduates); the quality of training in a secondary school, i.e. the ability of applicants to pass entrance exams positively; statistics of expulsion from the university (on academic performance or in violation of contractual obligations).

The desires of students and their parents are formed from many objective and subjective assessments:

- the prestige of a particular specialty;

- compliance with family traditions;

- awareness;

- the possibility of employment in the future;

- working conditions; 
Направление 2. Сотрудничество бизнеса и вузов: лучиие европейские практики. Российский и Казахский onblm

- the prevailing salary.

Therefore, it is necessary to clarify among potential applicants on the nomenclature of specialties of the university, as well as on the quality of education, on the employment program, social conditions for students, the cultural and social life of the university and so on. To this end, promotional materials, flyers, articles and so on are being developed; "open door days" are being organized; information boards of the selection committee are created; advertisements are published in the media (radio, television and print); Speaking on television (radio) or publishing articles; information on enterprises / organizations is sent; school visits are organized.

A special role in the advertising company must be paid to organizations that are potential consumers of future graduates.

The management and employees of large organizations are almost always interested in the influx of well-trained specialists. A positive attitude of such an organization will provide an influx of applicants whose motivation for a particular specialty is supported by a guarantee of a future job. When conducting advertising, propaganda should be used by graduates of the university who occupy senior positions in government bodies, public organizations, enterprises and organizations; propaganda of successes of university students and their participation in student olympiads and competitions; events dedicated to anniversary dates in the life of the university; holding international and domestic conferences; propaganda of large scientists of the university, working, previously working or graduating from it; performance of the university staff in the media on scientific, technical, cultural and public issues; distribution of the works of scientists of the university; participation of university employees in the activities of various educational, methodological and expert councils; conducting olympiads for schoolchildren; conducting testing of knowledge of students for their successful preparation for admission to the university; University events; outreach concerts in schools by students and faculty of the University; design of advertising and information stands and posters; informing potential applicants about the conditions of study, living in hostels, opportunities for cultural and sports recreation; distribution of information to enterprises and organizations that may be potential consumers of graduates and who may send applicants to study; distribution of information and meetings with graduates of schools, colleges, technical schools; one-off special lectures in schools.

\section{Results}

The university considers the successful employment of graduates as the main indicator of the effectiveness of educational activities. The university encourages long-term multilateral cooperation with employers in order to update the content of educational programs in accordance with the demands of the labor market; attracts practical trainers from among employers to conduct training sessions, including on the basis of third-party organizations, as well as to participate in the final certification of graduates in order to ensure the competitiveness and demand for graduates of the university.

To facilitate employment, the Career and Professional Development Center operates, which ensures the involvement of employers in conducting various events 
on the basis of the university in order to inform students and graduates of the university about employment opportunities and professional internships.

The faculties provide constant communication with the labor market through the Councils of employers, formed from among the graduates of the faculty. The authority and the work plan of the Council of Employers are determined by the faculty leadership on the basis of the current and strategic tasks facing the faculty.

An analysis of the effectiveness of the Council of Employers is carried out by the Academic Light of the faculty at least 2 times a year with the involvement of students and faculty. Based on the results of the analysis, the Faculty Academic Council makes recommendations, monitoring of which is carried out on a regular basis by the faculty's methodological bureau.

Students and graduates of the university have the opportunity to submit their resume for consideration by potential employers, as well as get acquainted with the available vacancies through the corporate portal «Youth and Career».

Students studying higher education programs (undergraduate) in pedagogical and medical specialties on the basis of the state educational order, also students of postgraduate education programs (master's and doctoral programs on the basis of the state educational order at the graduation course are subject to mandatory distribution in the organization of the corresponding profile for compulsory completion after graduation in accordance with the law Republic of Kazakhstan.

Graduation is distributed by a specially created distribution commission, which meets annually until June 1 of the calendar year.

A graduate of each level of education personally signs a personal distribution protocol for his faculty. This protocol is signed by the faculty personal allocation commission and is submitted to the Career and Professional Development Center until June 1 of the calendar year.

Exemption from mining is carried out in the manner prescribed by the legislation of the Republic of Kazakhstan.

Graduates who have studied under the state educational order and do not wish to fulfill their fulfillment obligations are required to return the financial resources spent on their training in full to the Financial Center of the Ministry of Education and Science of the Republic of Kazakhstan. Otherwise, the state budget funds spent on their training are recovered by the Financial Center in a judicial proceeding.

In Kazakhstan, state regulation of employment, which has the following structure:

- Ministry of Labor and Social Protection (function: analysis of processes developing in the labor market, forecasting, development and implementation of employment programs);

- State Employment Service (function: informs about the state of the labor market)

- The Department of Employment under the Ministry of Labor and Social Protection (interacts with government bodies, local executive bodies, employers);

- Regional, city employment centers - labor exchanges (analysis of socioeconomic changes in the region, organization of sociological studies for short-term and long-term forecast of the distribution of various categories of the population in 
Направление 2. Сотрудничество бизнеса и вузов: лучиие европейские практики. Российский и Казахский onbim

the labor market, forecast and analytical assessment of the staffing situation in the labor market (matching the professional composition of graduates and applying to the employment service demand on the labor market);

- Training and career guidance centers.

Youth Practice Program for University Graduates

Youth practice is organized for graduates of educational institutions in order to obtain graduates' initial work experience in the acquired profession (specialty). Youth practice is designed specifically for the unemployed from among the graduates of educational institutions implementing educational programs for technical and vocational, post-secondary, higher and postgraduate education in the profession (specialty) they completed, completed their studies within 3 years and no older than twenty-nine years.

Youth practice is organized in enterprises and organizations of all forms of ownership. Youth practice is carried out outside of permanent jobs and outside of vacancies for permanent jobs. Such jobs cannot be created in hard work, work with harmful and (or) dangerous working conditions. The number of jobs for youth practice may not be limited. Work on youth practice is temporary. The duration of youth practice is no more than 6 months. The amount of salary practice for youth practice per month from the republican or local budgets is 25 monthly calculation indices.

The program «With a diploma - to the village». For students who graduate from the university in the field of:

- education;

- healthcare;

- social Security;

- culture and sport;

- veterinary medicine.

The state offers rural work with appropriate social support. Social support for young professionals includes:

- provision of a lump-sum lifting allowance;

- the issuance of a budget loan for the acquisition and construction of housing for a period of 15 years;

- an increase in the official salary of not less than $25 \%$ of the tariff rates (in urban areas) to specialists of social institutions located in rural areas.

Youth Reserve Program. With the support of the Ministry of Education and Science of the Republic of Kazakhstan, the project «Youth Personnel Reserve» was implemented, aimed at identifying, selecting, training and educating the country's managerial personnel from among young talented, active students. The implementation of the project involves the identification, selection, training and education of the country's managerial staff, from among young specialists, and inclusion in socially significant activities in three areas:

- Public service.

- The business community.

- Social and political activities. 


\section{Conclusion}

It is necessary to create an information system-structural database on the qualitative and quantitative composition of city graduates and a bank of employers' business orders. Organize career building events. To conduct career day in educational institutions, a competition of professional presentation of students «Creativity is my profession», which allows students to demonstrate their skills, abilities and achievements that can interest the future employer.

Establish communication between students and employers, providing relevant information about the labor market.

Conduct «Job Fairs», «Career Days», information meetings, seminars, company presentations with graduates and students of pre-graduation courses.

Organize meetings with companies (Communication Day, Company Week, Student Dinner, Round Tables).

Maintain feedback with graduates, their subsequent retraining and advanced training in the university system.

To carry out joint activities of the university and employers on a long-term contractual basis on the issues of employment of graduates, increasing their competitiveness in the labor market.

Graduate departments should conduct work on the compilation and collection of resumes of students with the help of adviser curators.

The dean's office draws up a list of graduates for employment, where he notes:

- Graduates with guaranteed employment. For example, sent under contracts from organizations, or according to a rural quota;

- Graduates who do not need assistance in finding employment. For example, having an employment agreement or already having a job;

- Graduates in need of employment.

The graduating department carries out work on compiling and collecting resumes of students and plans activities for the employment of graduates based on the list of graduates provided by the dean's office. The Center for Career and Professional Development carries out work on the employment of graduates by searching for active organizations and sending them letters of invitation to conclude an agreement on cooperation in the employment of graduates; conclusion of cooperation agreements with organizations in need of personnel; selection of candidates based on agreements with organizations to provide them with personnel with the required level of training; organization of company presentations for the employment of graduates; organization of participation of students and graduates in job fairs; Assistance in sending students to practice in an organization where their further employment is expected; student advice on employment issues; mailing resumes of students by relevant organizations; work with employment centers / agencies; organization of work of the commissions for the distribution of graduates; organization of receiving feedback from employers on satisfaction with the quality of vocational training of graduates; organization of receiving feedback from graduates on satisfaction with the quality of received training; analysis of data from the State Center for the Payment of Pensions on the actual employment of graduates; maintaining records on the employment of graduates and reporting. 
Направление 2. Сотрудничество бизнеса и вузов: лучиие европейские практики. Российский и Казахский onblm

The EU legislation on practical education is one of the most advanced in the world and therefore is an excellent standard for productive changes in the legal framework of partner countries on this issue. Due to differences in education, technology, social environment between the EU countries and partner countries, the methods that are most applicable in the Russian and Kazakhstan markets will be studied. The selected methods of cooperation with business universities will be formed into a system aimed at filling the gaps between the needs of employers and the preparation of universities. The resulting system of cooperation with business universities is designed to increase the competence of students in all universities with some variations.

\section{References}

1. The academic policy of KazNU named after al-Farabi, 2019. [Electronic resource]. Mode of access https://www.kaznu.kz/ru/20575/page/

2. Employment of graduates [Electronic resource]. - Mode of access https://egov.kz/cms/ru/articles/vipusknik

3. The program «Youth Practice» for university graduates [Electronic resource]. - Mode of access http://kazast.kz/ru/program- youth- practice- for /

4. Practical aspects of interaction between a creative university and employers [Electronic resource]. Mode of access https://akvobr.ru/prakticheskie_aspekty.html???history=0\&pfid=1\&sample=33\&ref=0

5. Rules for the promotion of employment [Electronic resource]. - Mode of access https://www.zakon.kz/4850861-v-rk-chastichno-izmeneny-pravilapo.html???history $=0 \&$ pfid $=1 \&$ sample $=25 \&$ ref $=2$ 